\title{
EXPLORATION OF THE METHOD OF TRACING THE BOUNDARY AND PATTERN OF THE IMPERIAL GARDEN BY FOLLOWING THE TRACES OF HISTORY - TAKING CHANGCHUN GARDEN AS AN EXAMPLE
}

\author{
GuXin Song \\ BEIJING RE-YUANMINGYUAN COMPANY LIMITED， 3rd Floor, Building 1, No.41 Shangdi West Road, Haidian District, \\ Beijing - songguxin@thid.cn
}

KEY WORDS: Disappear , Royal gardens , Historical materials, Discernment, Changchunyuan, Digitization, Restoration.

\begin{abstract}
:
In the process of digital restoration of cultural heritage, for the disappeared royal gardens, where information is relatively scarce, the process of accurate digital restoration usually encounters a problem of how to effectively use the fragmented and limited historical and status quo information for discernment, to achieve accurate digital alignment restoration of the disappeared royal gardens in the region, and to complete the overall digital restoration of boundaries and patterns. Taking Changchun Garden as an example, this paper uses recent status quo mapping, aerial photography and current status quo structures as the basis, historical archival materials, style house plans, early mapping, early aerial photography and various historical documents as the starting point for the credibility and priority of various materials, and uses the iconic remaining information of key locations, such as buildings, water systems and fences, through historical traces, relative positions and proportional relationships. The identification of the 'line' is done by using the 'point' to determine the location of the wall in the east, north, west and south directions, thus defining the boundary and pattern of the historical Changchun Garden. This approach is based on the disappearing royal gardens and the digital restoration process can be effective in completing the task of solving problems and giving ideas and directions to those working in the relevant fields.
\end{abstract}

\section{INTRODUCTION}

\subsection{Questions}

The process of digital restoration of cultural heritage generally involves acquiring basic data through $3 \mathrm{D}$ laser scanning and tilt photogrammetry to achieve highly accurate regional alignment and digital restoration. However, based on the disappeared royal gardens, where information is relatively scarce, the process of accurate digital restoration usually encounters the problem of how to effectively use the scattered and limited historical and current information for identification, to achieve accurate regional digital alignment of the disappeared royal gardens and to complete the overall digital restoration of boundaries and patterns. The definition of boundaries and patterns is an important element of the digital restoration process, and if the identification method is not appropriate, the results of the same data will be very different or will take many detours before an accurate restoration can be achieved, and will directly affect the rest of the digital restoration work. In my own work and in studying the results of others, I have found that the recovery process is flawed due to inappropriate methods, and I have taken many detours and done some useless work. So this time, based on experience, I have summarised some methods and suggestions to take the opportunity to help those who work in the field.

\subsection{Relevance}

Such problems were encountered during the digital restoration of the Changchun Garden. The Changchun Garden was an early imperial garden of the Qing Dynasty, a typical imperial garden like the Summer Palace, but today the original site is completely untouched by buildings, with only two temple gates remaining to bear witness to its existence. The only information available on the Changchun Garden is a simple hand-drawn plan from the mid to late Qing dynasty and some scattered historical information, only the general area of the imperial garden is known. The Changchun Garden is a typical disappearing royal garden.To recreate the full shape of the imperial garden in its heyday, a general plan with accurate boundaries and layout is essential. The following are some of the methods and tools we have used in our work to digitally restore the Imperial Garden.

\section{THE SOLUTION}

\subsection{Preliminary work}

The first thing we need to determine in the early stages of digital restoration is the time and scope of the restoration. This requires a good knowledge of the history of the garden's changes, and the formation of a chain of evidence by sorting out the information that the various sources can provide to corroborate each other. The first thing we need to know is that the boundary of the wall of the Changchun Garden has changed at different times, following the reconstruction and expansion of the palace gate area after the Wanshou celebrations in the 52nd year of the Kangxi era, plus the later construction of the Enyou and Enmu temples, and the encroachment of the Chengze Garden in the north-east in the 25th year of the Daoguang era. This restoration locates the point in time when the imperial garden was in its prime during the Kangxi period in the early Qing dynasty.

This imperial garden, Changchunyuan, built on the site of the former Qinghua Garden, Start of office at the main entrance of Changchunyuan in February 1687 (Kangxi year 26), through its alteration and expansion after the Wanshou celebration in 1713 (Kangxi year 52), to the construction of Enyou and Enmu temples. From the forty-second year of the Qianlong reign (1777), when it was designated as the Empress Dowager's 
Garden, to the twenty-third year of the Daoguang reign (1843), when the officials of the Changchun Garden were all allocated to the Yuanmingyuan and relegated to a subsidiary garden, then the twenty-fifth year of the Daoguang reign (1845), when the north-western part of the Changchun Garden was encroached upon by the Chengze Garden, to the sixth year of the Xianfeng reign (1856), when some of the wood of the main buildings was demolished to offset other uses, to the tenth year of the Xianfeng reign (1860), when the invaders burned it down The Royal Garden has undergone several changes. The only two remaining gates on the site today are the Enyou Temple and the Enmu Temple, built in the first year of the Yongzheng era (1723) and the forty-second year of the Qianlong era (1777) respectively. As can be seen from the chronology of the Changchun Garden, the imperial garden was in its prime during the Kangxi period in the early Qing dynasty, after the 52nd year of the Kangxi era (1713) and before the first year of the Yongzheng era (1723).

\begin{tabular}{|c|c|}
\hline Era & Events \\
\hline Kangxi 23rd year (1684) & $\begin{array}{l}\text { Settled as a royal garden } \\
\text { and began construction }\end{array}$ \\
\hline Kangxi 26th year (1687) & $\begin{array}{c}\text { Start of office at the main } \\
\text { entrance }\end{array}$ \\
\hline Kangxi 52th year (1713) & Alterations, extensions \\
\hline $\begin{array}{l}\text { The first year of the } \\
\text { Yongzheng reign (1723) }\end{array}$ & $\begin{array}{c}\text { Construction of Enyou } \\
\text { Temple }\end{array}$ \\
\hline $\begin{array}{l}\text { The } 42 \text { nd year of the } \\
\text { Qianlong reign (1767) }\end{array}$ & $\begin{array}{l}\text { Construction of the Temple } \\
\text { of Enmu, designated by } \\
\text { decree as the Queen } \\
\text { Mother's Garden }\end{array}$ \\
\hline Daoguang 23rd year (1843) & $\begin{array}{l}\text { The officials are all } \\
\text { allocated to the } \\
\text { Yuanmingyuan and } \\
\text { relegated to the subsidiary } \\
\text { gardens }\end{array}$ \\
\hline Daoguang 25rd year (1845) & $\begin{array}{l}\text { The north-western part of } \\
\text { the Changchun Garden is } \\
\text { encroached upon by the } \\
\text { Chengze Garden }\end{array}$ \\
\hline $\begin{array}{l}\text { The Sixth Year of Xianfeng } \\
\text { (1856) }\end{array}$ & $\begin{array}{l}\text { Major building demolition } \\
\text { of part of the timber to be } \\
\text { offset for other uses }\end{array}$ \\
\hline Ten years of Xianfeng (1860) & $\begin{array}{c}\text { Burned down by the } \\
\text { invaders and reduced to } \\
\text { rubble }\end{array}$ \\
\hline
\end{tabular}

Table 1. Chronology of the Great Chronicle of Changchun Garden.

\subsection{Method of implementation}

Following the traces of history, on the basis of survey maps, archaeological maps, aerial photographs, stylised house plans and various historical sources, all the information was sorted out and divided into different levels according to the credibility of the sources shown in Table 2, with credibility $\mathrm{A}>\mathrm{B}>\mathrm{C}, \mathrm{A} 1>\mathrm{A} 2$. A, the highest credibility level, was used as the basis for quantification, while $\mathrm{B}$, the credibility level of historical map archival information, was qualitative, That is, the relationship of mutual position, proportionality. and $\mathrm{C}$, the lowest credibility level of relevant circumstantial evidence, was used to supplement. In brief, the highest credibility level, A, is used as the basis for quantification, while the highest credibility level, B, is used for characterisation, and the lowest credibility level, $\mathrm{C}$, is used to supplement and complete the map.

Firstly, we use the 2000-2003 mapping of Haidian District in Beijing (hereafter referred to as the 2000 mapping), which has the highest level of credibility, to compare with the 1954 mapping of Haidian District (hereafter referred to as the 1954 mapping), the earliest mapping of the garden, to observe the overall changes, and to study and locate the boundaries and pattern of Changchun Garden from the current state of the site. From the study of historical data, it is clear that the two existing gates of Enyou Temple and Enmu Temple, shown at point a in the map, were built on the eastern wall of Changchun Garden, in the north-eastern corner of the entire imperial garden. We can clearly see the two gates through the 1945 aerial photograph

(U.S. National Archives Collection), and we can also see a small winding river ditch in the north and the path between the Changchun Garden and the northern royal residence, Hanfang Garden, and the river is extended across the east side of the road to the opposite side, which is in line with the full map of the situation of the Changchun Garden in the Palace Museum collection - March 29th, 16th year of the Daoguang era (sample 1324), hereinafter referred to as " sample 1324".The northeastern corner of the wall is not far north of this small river,located at point $\mathrm{b}$. A line is then drawn along the ridge of the two gates to accurately delineate the north-eastern boundary of the Changchun Garden.

\begin{tabular}{|c|c|c|c|c|}
\hline \multicolumn{2}{|r|}{ Source } & \multicolumn{2}{|c|}{$\begin{array}{l}\text { Credibil } \\
\text { ity level }\end{array}$} & Role \\
\hline \multirow{2}{*}{$\begin{array}{l}\text { Geographic } \\
\text { al } \\
\text { information } \\
\text { material on } \\
\text { the site }\end{array}$} & $\begin{array}{l}\text { Site status, mapping, } \\
\text { archaeological } \\
\text { material }\end{array}$ & A & A1 & \multirow[t]{2}{*}{$\begin{array}{l}\text { Quantitat } \\
\text { ive }\end{array}$} \\
\hline & $\begin{array}{c}\text { Satellite imagery, } \\
\text { aircraft aerial } \\
\text { photography }\end{array}$ & & A2 & \\
\hline \multirow{3}{*}{$\begin{array}{l}\text { Historical } \\
\text { information }\end{array}$} & Old Photos & \multirow[t]{3}{*}{ B } & B1 & \multirow{3}{*}{$\begin{array}{l}\text { Qualitati } \\
\text { ve }\end{array}$} \\
\hline & $\begin{array}{l}\text { Historic archives, } \\
\text { style house plans }\end{array}$ & & B2 & \\
\hline & Textual History & & B3 & \\
\hline \multirow{3}{*}{$\begin{array}{l}\text { Relevant } \\
\text { circumstant } \\
\text { ial evidence }\end{array}$} & $\begin{array}{c}\text { Similar examples } \\
\text { (With physical } \\
\text { remains) } \\
\end{array}$ & \multirow[t]{3}{*}{$\mathrm{C}$} & $\mathrm{C} 1$ & \multirow[t]{3}{*}{$\begin{array}{c}\text { Supplem } \\
\text { entary }\end{array}$} \\
\hline & $\begin{array}{c}\text { History } \\
\text { (Textual history, } \\
\text { historical archives, } \\
\text { old photographs) }\end{array}$ & & $\mathrm{C} 2$ & \\
\hline & $\begin{array}{l}\text { Previous research } \\
\text { (Related research } \\
\text { monographs, books } \\
\text { and papers) }\end{array}$ & & $\mathrm{C} 3$ & \\
\hline
\end{tabular}

Table 2. Corresponding table of sources, credibility levels and roles.

It is worth noting that the two gates are not oriented in the same direction; the En You Temple gate on the north side is about 12 degrees further to the right than the En Mu Temple gate on the south side, so the east wall line as a whole is not a straight line, but it is not obvious from the outside; a photograph of this section in the late Qing and Republican periods gives a visual indication of the situation.

With very little information on the subject, we then thought of looking for new clues by studying the information around the imperial garden. We were able to obtain new information from the Chengze Garden and the Hanfang Garden in the northern 
part of the Changchun Garden. The National Library's publication "The National Library's Collection of Style Lei Archives - The Royal House Volume", which contains the style house plans of Chengze Garden and Hanfang Garden, was a great help to us. We were also surprised to find traces of the southern courtyard wall of the Chengze Garden from the 25th year of the Qing dynasty (1845) clearly preserved on the 1954 mapping, thus identifying the western section of the northern courtyard wall.

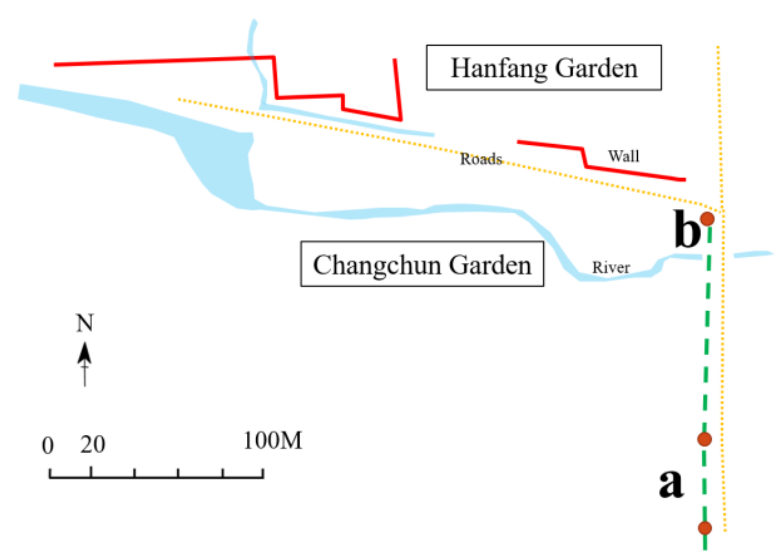

Figure 1. Diagrammatic representation of the north-eastern boundary identification.

The location of the eastern section of the north wall was confirmed by using the full map of the Hanfang Garden site (Sample 113-0003), hereinafter referred to as "Sample 1130003", for comparison, and found that the 1954 survey map could also be used to find a correspondence between the three pile houses on the south side of the Hanfang Garden, the river canal connecting the two gardens and the large north wall of the Changchun Garden. The north wall boundary was then completed in conjunction with "Sample 1324". "The relationship between the buildings, the river and the wall in this section of 'Sample 113-0003' and 'Sample 1324' is basically the same, except that the north wall of the Changchun Garden in 'Sample 113-0003' is drawn straighter. The northern boundary wall of the Changchun Garden is drawn flatter, indicating that they are still very reliable. This completes the identification of the northern boundary of the entire Changchun Garden.
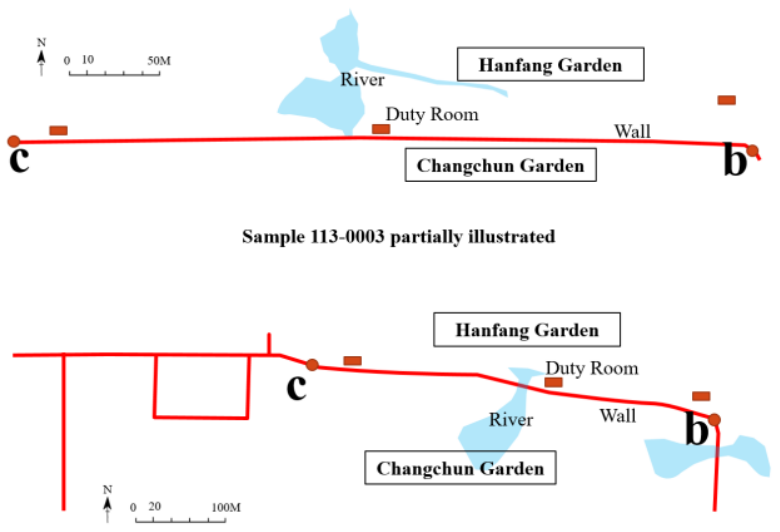

Sample 1324 partially illustrated

Figure 2. Analysis of the eastern boundary of the northern wall of Changchun Garden.
The western boundary of the Changchun Garden, which has no remaining buildings is essentially a large area of farmland and open space and can only be surmised by the relative position of the river system. It is valuable to use the position of the fivehole gate and the relationship of the river through the wall to analyse the alignment.

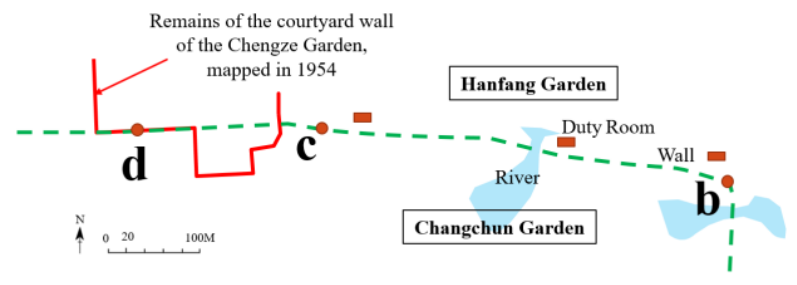

Figure 3. Complete analysis of the northern wall boundary of the Changchun Garden.

It is important to note here that one cannot rely on one point alone as a reference point. After a comparative analysis of several drawings of the Chengze Garden style house in the National Library collection (National Library Collection of Style Lei Drawings Archive - Wang Gong Fu Di Volume), the historical location of the five-hole gate has been altered. The relationship between the position before and after the alteration can be clearly seen on the Seung Chak Yuen site house sample 118-0029 (hereinafter referred to as sample 118-0029) from the 25 th year of the Daoguang era. Secondly, there is a vertical line of extension on this drawing presumably the western wall of the Changchun Garden. From this we can tentatively identify point e as the point where the north and west walls meet.

So where exactly is the western boundary of the enclosure and how do we locate it? We can first look at the south-western part of the Changchun Garden, where there is a rich water system. Using the ground elevation difference shown on the 1954 survey map, combined with the location of the water system and the relationship between the buildings outside the south-western enclosure, is one of the important means of examining the south-western boundary. After careful analysis the location of point $\mathrm{g}$ can be confirmed. This, together with point e, allows for the initial location of the western boundary wall.

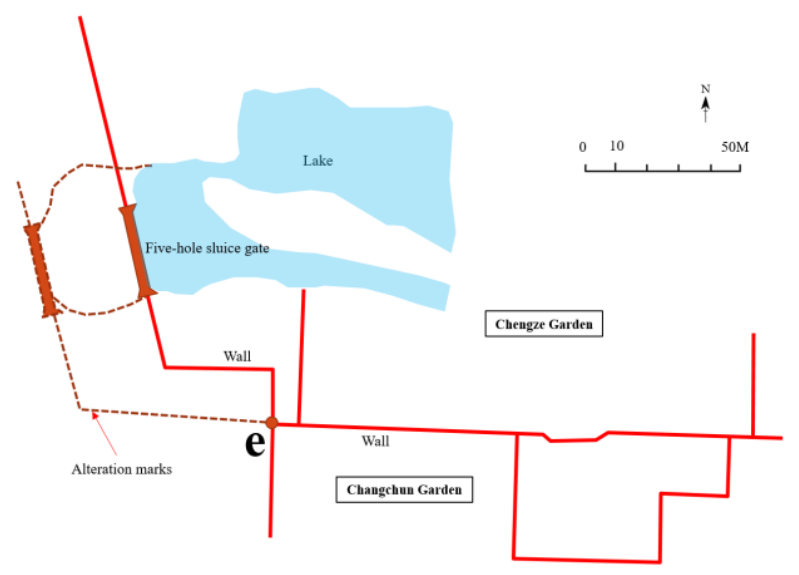

Figure 4. Sample 118-0029 illustration - partial .

We were delighted to find that several of the rivers entering and leaving the garden could be traced in the 1954 mapping. Combined with point "h", the location of the southern boundary wall shown on the archaeological site plan of the Great Palace 
Gate in Changchun Garden, its extension line was connected to the extension lines of the eastern and western boundary walls to obtain points $\mathrm{g}$ and $\mathrm{i}$, which intersected to form the complete boundary of the wall. The position of the south-eastern corner of the wall can also be corroborated by the relationship between the water system here and the position of the imperial road. The imperial road shown by the yellow line is today's Summer Palace Road, which in the 1950s was called Jing Yi Road. The location of the Palace Gate area, surrounded by water and ditches to the south of the wall, can also be seen at a glance.

At the same time, we can also check the accuracy of the location of the east and west boundary walls by using the better preserved and easily locatable Rui Zhu Yuan site, point K, from the 1954 survey map, to corroborate each other's credibility and allow the chain of evidence to form a closed loop. The ratio of the distance from the western boundary of Rui Zhu Yuan to the western boundary wall fk of Changchun Yuan to the distance from the eastern boundary of Rui Zhu Yuan to the eastern boundary wall kj of Changchun Yuan, as shown on Style Lei drawing 1324, verifies the location of the eastern and western walls of Changchun Yuan. So far the Kangxi Sheng time Changchun Garden boundary and pattern test is basically complete.

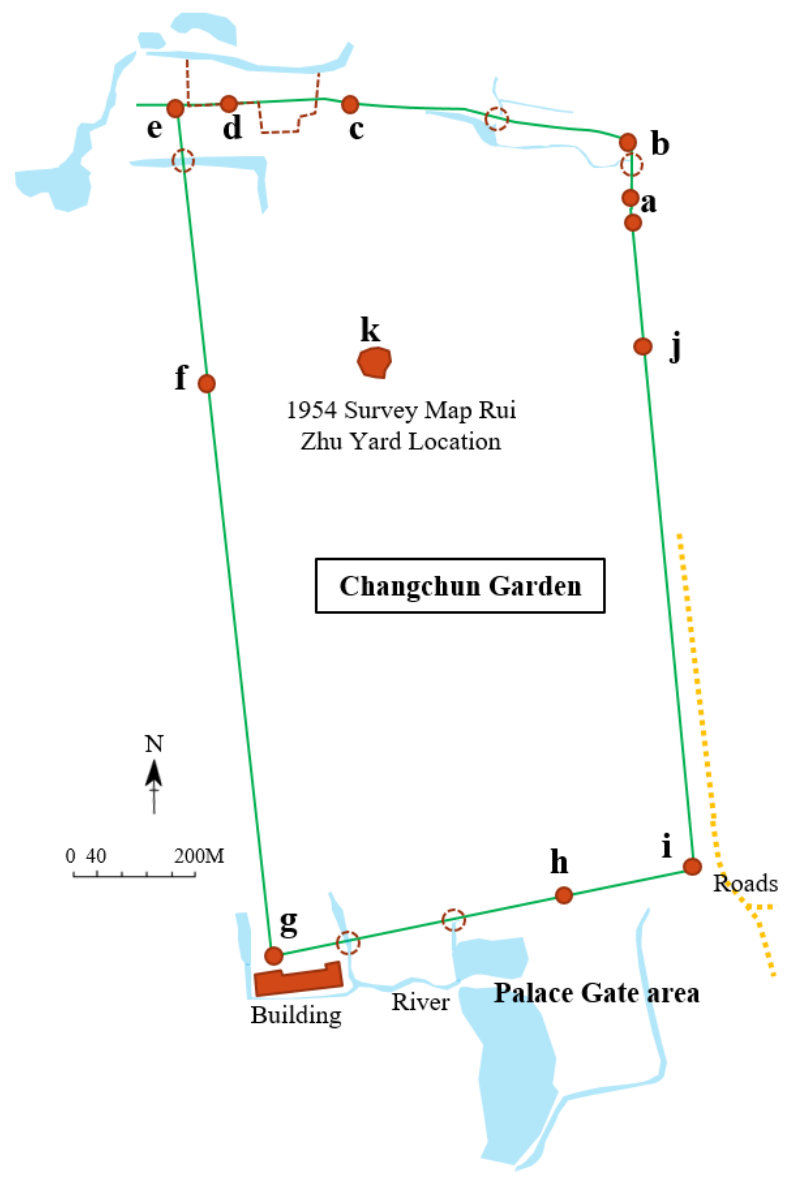

Figure5. Full map of the boundaries and layout of the Changchun Garden.

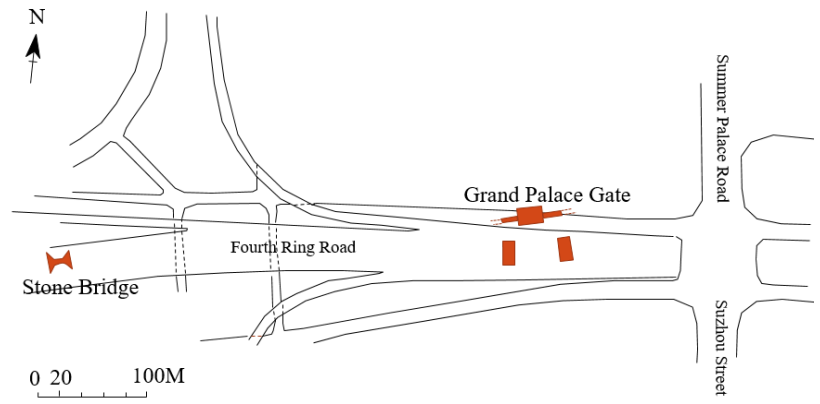

Figure 6. Map showing the location of the archaeological site of the Great Palace Gate in Changchun Garden.

\section{CONCLUSION}

In the process of digitising cultural heritage, based on the disappeared royal gardens and with limited information, the following recommendations are made in the process of accurate digital restoration.

1. first sort out the level of credibility of the data, and use the ones with a high level of credibility for the base drawings.

2. sort out what is to be used for quantitative purposes and what is to be used for qualitative purposes.

3. pay attention to the use of information from neighbouring sites in the vicinity.

4. pay attention to the use of more accurate drawings obtained by current technological means.

5. taking care to look for traces of history and to select objects that are distinctive, easily recognisable and not easily altered as references.

6. attention to cross-corroboration between different sources, with multiple data forming a closed chain of evidence between them.

On the basis of the above work, each of the authenticated points will be linked into a line, and the final positioning of the area will be completed, so that a digital restoration can be created that will stand up to scrutiny and more accurately restore the historical imperial garden.

\section{REFERENCES}

National Library Publishing House, 2020. National Library Collection of Style Ray Picture Archives - Wang Gong Fu Di Volume.

Yu Minzhong et al. Qing. The old news under the sun.

Wang Ix. Qing. The First Collection of the Wanshou Celebration, Volume 42.

Zhang Baozhang. 2018. Changchunyuan.

Kan, Hongliu. 2015. Changchunyuan Study.

Collection of the National Palace Museum, 1836. Alignment Sample of March 29th, 16th Year of Daoguang (Sample 1324). 
Survey and Mapping Team, Beijing Municipal People's Government Construction Affairs Bureau, 1954. Topographic map of the vicinity of Haidian District, Beijing.

Beijing Institute of Surveying and Mapping Design, 2000-2003. 2000-2003 Survey and Mapping Map of Haidian District, Beijing.

Wang Qinglin, Wang Ce, Zhu Zhigang, Zhou Yu. , 2003. Excavation Brief of the Great Palace Gate Building Site and West Garden a Stone Bridge Site in Changchun Garden, a Famous Garden of Qing Dynasty. Beijing Wenbo 2003(3), 2329.

Cui Shan, Wang Qixing, Cui Jingshu., 2019. Speculation on the plan layout of Changchun Garden in the Kangxi period and the analysis of its garden landscape titles[J]. Chinese Garden,2019,35(05):128-133. 